\title{
Using 'The Corporation' As A Powerful Illustration Of Ethical Issues Facing The Financial Manager
}

Patty Hatfield, Bradley University, USA

\begin{abstract}
Traditional undergraduate students lack the business experience or frame of reference to enable them to understand the potential conflicts of interest that occur in every day business. In the wake of the corporate scandals that has shaken the financial world, emerged the realization that some corporate cultures are legally corrupt or at the very least, behave unethically. Students need to be made aware of the potential conflicts that lie ahead. Corporate cultures are often not transparent and may not be what they appear to be. Students need to develop skills and awareness that will allow them to personally assess the harm and benefit of business decisions, not just for the shareholder but for all stakeholders of the company. The documentary, 'The Corporation' can be used as a valuable teaching tool to provide students with a context and imagery that allows them to, in a sense, experience the issues, thereby making the material more relevant and creating a more pronounced impression on the student. For graduate students the documentary can be used as a platform for lively discussion with regard to issues they have come across or could potentially encounter. The purpose of this article is to provide a segment breakdown of the movie with suggested discussion questions for a lively class exchange.
\end{abstract}

Keywords: ethics, social responsibility, stakeholders, decision-making, profit

\section{INTRODUCTION}

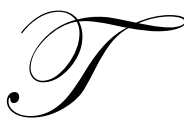

he award winning documentary, The Corporation, can be effectively used as an innovative teaching tool to illustrate fundamental conflicts that often occur as a result of the corporate mission of maximization of shareholder wealth. In an era that relies on legislated ethics as opposed to the integrity of our leaders, it is more important than ever to provide opportunities for students to develop independent and critical thinking skills. Students need to be aware that the business decisions they soon will encounter may often entail balancing corporate mission with basic business ethics. However, the traditional undergraduate student often lacks the exposure necessary to understand the types of future dilemmas she/he will likely encounter. Real life illustrations of ethical dilemmas that confront firms everyday, re-enacted or discussed by businessmen/women involved in the issues, is an effective way to expose students to some of these issues with the added benefit of capturing their interest. This paper provides information on how the documentary, The Corporation, can be used as a live illustration of ethical dilemmas that commonly occur in the business world. Discussion questions are provided to enhance dialogue on issues related to the often-divergent interests of the maximization of shareholder wealth and sound business ethics. The case is versatile and may be used as the basis for lively ethical discussions in a variety of graduate and undergraduate business courses.

\section{LITERATURE}

Dyl (1991) was the first to describe the benefits of using the movie Wall Street as a "live case" illustrating ethical issues. Dyl describes how movies can be used as a catalyst for classroom discussions that are lively and informative. Chan, Weber and Johnson (1995) provide guidelines on how the movie Other People's Money can be used in teaching financial concepts such as shareholder wealth maximization, capital structure decisions and mergers 
and takeovers. Others such as Harrington and Griffen (1989) and Serey (1992) have used the movies Aliens and Dead Poets Society to teach lessons of leadership and management. Nofsinger (1995) describes how the movie Barbarians At The Gate can be used as an illustration of a variety of financial concepts such as, agency problems, capital budgeting, leverage, valuation and capital structure. Barbarians At The Gate has an added benefit over its predecessors in it's story is true. The portrayal of the actual battle for and eventual takeover of RJR Nabisco adds another element of realism to the discussion. Hatfield and Buchko (2008) provide discussion questions, answers and supplementary reading suggestions for the Academy Award nominated documentary, "ENRON: The Smartest Guys In the Room." This movie contributes another dimension of realism in that it is not only a true story but there is no acting in the film. The movie is a collection of video, interviews and audio tapes of executives and traders of Enron with commentary provided by Bethany McLean and Peter Elkind, authors of the book, The Smartest Guys in the Room. Likewise, The Corporation, is a documentary based on forty interviews with corporate insiders skillfully composed resulting in a documentary that has won ten Audience Choice Awards. The fact that there are no actors ensures that any character dramatizations are minimal.

\section{THE CORPORATION DOCUMENTARY}

The Corporation is a documentary that provides a challenging view of corporations' responsibilities to all members of society. The documentary has a running time of 145 minutes. Exhibit 1 breaks the movie down by its natural segments and provides a topical overview of each segment. The instructor can use the elapsed time information to estimate the best place to stop the movie based on the amount of class time available. A list of sample discussion questions along with commentary is provided to help instructors anticipate the direction of the class discussion.

Exhibit 1: The Corporation

\begin{tabular}{|c|c|c|}
\hline $\begin{array}{c}\text { Time } \\
\text { elapsed }\end{array}$ & $\begin{array}{l}\text { Movie Segment } \\
\text { Title }\end{array}$ & Description \\
\hline & Introduction & Movie begins by defining a corporation. \\
\hline $0: 06$ & Birth & Original purpose of the corporation. \\
\hline $0: 11$ & A Legal Person & How a corporation came to have the same rights as a legal person. \\
\hline $0: 18$ & Case Histories & \\
\hline $0: 25$ & Dangerous Products & $\begin{array}{l}\text { Describes how some corporations manufacture and sell what they know to be } \\
\text { dangerous products. }\end{array}$ \\
\hline $0: 29$ & Harm to Animals & $\begin{array}{l}\text { Describes how Monsanto markets the use of BST (Bovine Somatotropin) injections } \\
\text { for dairy cows to increase milk production. Harsh side effects to cattle and risky } \\
\text { for the consumer. }\end{array}$ \\
\hline $0: 33$ & $\begin{array}{l}\text { Harm to the Biosphere/ } \\
\text { Environment }\end{array}$ & $\begin{array}{l}\text { Firms damage the environment/biosphere and even legislation doesn't stop it from } \\
\text { occurring. }\end{array}$ \\
\hline $0: 40$ & Pathology of Commerce & To what extent is a corporation a psychopath? \\
\hline $0: 42$ & Monstrous Obligations & $\begin{array}{l}\text { Describes how those that investors rely on to monitor managerial actions were } \\
\text { going along with the fraud. Investment bankers, auditors, and attorneys all profited } \\
\text { from the fraud. }\end{array}$ \\
\hline $0: 47$ & Mindset & Provides examples of the mindset of executives as they seek to make profits. \\
\hline $0: 57$ & Boundary Issues & Privatization vs. Public Institutions \\
\hline 1:03 & Basic Training & How marketing targets children. \\
\hline $1: 13$ & Perception Management & $\begin{array}{l}\text { Describes how corporations spend billions of dollars to manage their public } \\
\text { perception and shape political opinions. }\end{array}$ \\
\hline $1: 18$ & A Private Celebration & $\begin{array}{l}\text { Discussion on branding. And how people (Martha Stewart) and towns (Celebration, } \\
\text { FL) become a brand. }\end{array}$ \\
\hline $1: 21$ & Triumph of the Shill & Discussion on product placement. \\
\hline $1: 25$ & Advancing the Front & $\begin{array}{l}\text { How new life forms and other scientific discoveries are considered intellectual } \\
\text { property. }\end{array}$ \\
\hline $1: 30$ & Unsettling Accounts & How corporations control the media. \\
\hline $1: 40$ & Expansion Plan & How U.S. Corporations trade with countries that are the enemy of the U.S. \\
\hline $1: 59$ & Democracy LTD & Democracy is not well understood by corporations. \\
\hline $2: 02$ & Psycho-Therapies & Ways to address issues of corporate power. \\
\hline $2: 19$ & Prognosis & An appeal to limit the power of the corporation. \\
\hline
\end{tabular}




\section{DISCUSSION QUESTIONS}

\section{What is business ethics? What underlying question must be answered in order to assess whether a corporation's managers participate in ethical business transactions and ethical decision-making?}

A variety of answers will come from this question. There does not appear to be a universal definition of business ethics. Ethics in general examines human behavior and actions with regard to what is right and wrong, fair and unfair, just and unjust. Thus, business ethics examines issues within the context of the business environment. What business practices are right or wrong? Fair or unfair? Good or bad? Beneficial or harmful? If a conflict of interest exists, then the most ethical response would be to act in such a way to bring harmony and reconciliation of conflicting interests.

In order to determine whether a decision is ethical, we must first understand the purpose of a corporation. If the purpose of the corporation is to make profits and operate strictly in the interest of the shareholders, then it could be argued that any energies or monies spent for other interests would be unethical since it would come at the expense of shareholders. The documentary tracks the history of the corporation and its original intent. Originally corporations were given limited life spans and could only participate in very defined and specific activities over a limited life. The purpose of the corporation was to create a social or public benefit and was subject to the direction and regulation of government. Corporations were not permitted to influence elections or public policy. However, today, due to a court decision intended to protect the human rights of former slaves, the corporation has the same rights as a human being. This marked an important turning point with regard to the shift of power away from government and society, to the corporation. Over time the corporation has become the most powerful entity in the U.S., more powerful than the U.S. government.

So, what is the purpose of the corporation? If it exists for its original purpose, then it is here to benefit all stakeholders. Therefore, any actions taken to benefit shareholders at the cost of the rest of the stakeholders must be considered unethical. Thus, under this constraint, managers should work to reconcile the conflicts inherent in business decision-making. The remaining discussion will operate under the assumption that the corporation exists to benefit all stakeholders.

\section{Does "legal" equal "ethical?"}

Often times, practitioners may defend questionable behaviors by stating that their actions are not illegal. This defense implies that any corporate activity that is legal, is acceptable. The obvious danger with this is that generally laws reflect a minimal acceptable behavior, a far cry from most ethical behavior. As Archie Carroll (1998) argues, laws and regulations generally lag behind ethical thinking. Laws and regulations are often created after a new type of "crime" has been committed. As a result, they do not reflect the latest thinking, trends, technological advances or general standards that managers should follow in order to protect the stakeholders of their corporation and are often incomplete in their protection. ${ }^{1}$

To further demonstrate the insufficiency of legality as a determinant of ethical standards, we only have to look in the area of financial reporting to see how incongruent the two can be. Financial reporting has been one of the most tightly regulated areas of corporate management and yet we have seen one corporate scandal after another emerge. The exploitation of loopholes and "gray area" in the accounting rules have permitted sly managers to realize fraudulent profits, many without ever breaking the law. "The Corporation" provides several additional illustrations of corporate behavior that is legal but unethical. One example is the sale of pollutant permits issued by the EPA with the intent of reducing harmful emissions into the air. Corporations are granted permits to allow them to release a certain amount of pollutants in the air each year. Rather than trying to minimize pollutants for the social good, many firms try to negotiate the highest quota with the EPA and then minimize pollutants for a profit. If a firm does not use its entire emissions quota then they can sell the excess emissions capacity to other firms, thereby allowing them to release pollutants beyond their quota. This is certainly legal, but is it ethical?

\footnotetext{
${ }^{1}$ Carroll, Archie B., “The Four Faces of Corporate Citizenship,” Business and Society Review, 100, (September 1998$)$, pp. 2.
} 
Many companies participate in various schemes in order to avoid paying taxes that are rightly due to host countries. The documentary points out that some companies are attracted to third world countries because of the huge tax abatements they offer because those countries are so desperate for jobs and some economic stability. Other companies use transfer pricing in order to avoid taxes. Still others seek to avoid taxes by incorporating in countries that do not require tax payments, like Bermuda. This all represent legal ways to avoid paying taxes to host countries as well as the U.S. government, but is it ethical?

3. Suppose a company makes a fair rate of return for its investors while also maintaining safe and secure working conditions for its employees. The management recognizes the importance of supporting the community and as such make regular and generous donations to various programs in the communities they serve. Would you conclude that this company is a good example of an "ethical" company? Why or why not?

After viewing the film, students should recognize that there is much more to ethical behavior than a fair rate of return and community support. What types of externalities does this company cause and what measures does this company take to become self-sustaining? The company gives generously to community organizations and these donations are generally very public events. In private, does the company participate in maneuvers to avoid paying taxes that they should pay and depriving society of dollars due to them? Public generosity is good but not at the expense of tax dollars that are aimed at necessary public services such as education. Thus, behaviors that occur "behind the scenes" are an important determinant of ethical standing.

The products or services produced by the firm also play a part in company's moral fiber. What if the company offers solid tax revenues, generous community support, a fair rate of return to investors and produces and exports to third world countries the 'terminator seed?' What if they supply computer equipment to help manage ethnic cleansing efforts in another part of the world? Or cigarette manufacturers produce pink and fragrant cigarettes to market to young adults and teens? The point is that one must also consider the products that are sold and the market that is being targeted. It may be something as subtle as commercials developed by psychologist to entice children in the age of obesity to nag parents to purchase sugary cereals and snacks. Is that ethical? Student responses will be mixed.

4. The documentary provides examples of a number of situations where decisions to maximize profits are controversial. Describe some of these situations? Would you consider all of these actions to be unethical? Are there ways to adjust these ventures so that all stakeholders benefit?

The documentary provided a number of business decisions made ultimately for financial gain. A list is provided below.

1. Sale of technology by IBM to Nazi Germany to help manage the Holocaust.

2. Hiring of a corporate spy to extract information form corporate executives.

3. Traders profiting from $9 / 11$ disaster.

4. Branding.

5. Advertisers hiring of child psychologist to maximize the nag factor for children's products.

6. $\quad$ The companies that help big corporations "have a voice."

7. Setting up sweatshops in third world or developing countries.

8. Production and sale of the terminator seed.

9. Companies trivialize petrochemicals that are known to cause harm but effects.

10. Using hormones or chemicals to increase milk production.

11. Pollution quota given to corporations by government.

12. Patenting intellection property such as finding a gene that causes cancer.

13. Media stop a story that does not release favorable news and may lose advertising dollars.

14. Companies that trade with countries that are official enemies of the U.S.

15. Dumping pollutants in nearby streams and oceans. 
Students will find that all of these have a profit motive and serve the shareholders and the executives of the companies. However, most students will argue that nearly all of these behaviors are unethical. The actions that may escape condemnation and receive more controversy are the branding and advertising issues and some students do not have an issue with industrial espionage.

It may be interesting to challenge them with the arguments that describe benefits associated with some of these actions. For example, with regard to sweatshops present the following case:

\section{FINANCIAL STRATEGY - EXPAND PRODUCTION AND DECREASE MARGINAL COST}

Suppose you wish to expand production to meet demand for your product in other countries. In order to be competitive in these markets, you will need to minimize costs. You can accomplish this by building a facility in a neighboring third world country. Wages would be much lower than U.S. wages and shipping costs would be much lower since you would be much closer to your international markets. The country would lure a company such as yours by offering significant tax abatements making the venture even more financially attractive. As the financial manager of this company, is it appropriate to take advantage of these factors when determining the value of the investment?

After watching the film, many students will likely argue that as long as you pay them fair wages then it is okay. Press them further on what they define as a fair wage and several may argue that paying close to U.S. wages is fair and that anything less would be exploitation.

However, proponents of so-called sweatshops argue the following. A corporation could, in fact, be a welcome opportunity for workers in third world countries to find jobs to allow them to support their families. Paying lower than U.S. salaries in itself may not be considered by some as immoral since U.S. wages are the highest in the world. In fact, some could argue, if they paid wages much higher than the domestic wage of firms in the host country, then the U.S. firm may damage host country firms and thus, its economy. Paying fair wages for that country is probably considered ethical, as well as providing safe working conditions for its employees. Outright exploitation, such as child labor and sweatshops viewed in the film are immoral and take advantage of a poor countries desperate search for economic relief. Some would further argue that accepting excessive tax abatements is also questionable. The company should certainly pay its fair share of taxes and not participate in tax avoidance schemes such as is the case with some transfer pricing.

An article by De George lists seven moral guidelines that apply to multinational companies (MNCs) operating in Third World countries. They are $^{2}$ :

1. MNCs should do no intentional and direct harm.

2. MNCs should produce more good than bad for the host country.

3. MNCs should contribute by their activities to the host country's development.

4. MNCs should respect the human rights of their employees.

5. $\quad$ MNCs should pay their fair share of taxes.

6. To the extent that local culture does not violate moral norms, MNC should respect the local culture and work with it, not against it.

7. MNCs should cooperate with the local government in the development and enforcement of just background institutions.

5. Can you think of any types of firms that have obvious conflicts of interest between shareholders and other stakeholders?

\footnotetext{
${ }^{2}$ De George, Richard T. "Ethical Dilemmas for Multinational Enterprise: A Philosophical Overview.” ???
} 
Students are likely to come up with several examples of things. Some noted examples include health insurance companies that operate for profit. These companies have an incentive to reject medical claims in order to boost their profits, an externality suffered by the "customer."

Oil companies have an incentive to keep Americans dependent on oil as opposed to alternative fuels in order to keep their profits high. Drug companies seek out a cure for cancer so they can patent the formula for profitable gain. Students will come up with a number of examples and the discussion can evolve around the question, "how do we fix it?"

\section{What is the underlying cause of most unethical managerial behavior and the resulting externalities that occurs in corporate America?}

There are a variety of responses to this question. Some students may argue that the pressure to make profits provide an incentive to seek out both ethical and questionable business opportunities. Others may argue that executive compensation and greed is the culprit. Some will argue that it is a by-product of a capitalistic society. In order to remain a viable entity you have to participate in those things necessary to survive competitive pressures.

\section{Can ethics by effectively legislated? If not, why is it not effective? Are there ways to make legislation more effective?}

Students will generally argue that legislation helps but is not sufficient to eliminate unethical behaviors. One problem is that legislative solutions are often a response to ethical problems and therefore a time lag exists. Furthermore, legislation does not inhibit many corporations from engaging in questionable activities. The documentary provides a list of companies that have violated various government legislation and, as a result, have been required to pay fines. For many companies, whether or not to adhere to regulation becomes a cost/benefit/risk analysis. In other words, "If I violate this law, what will the company gain? If I am caught, what are the probable costs involved? What is the probability of being caught?" Once all the factors are weighed, it may be more profitable to violate the law, take the chance that the company may be caught, or not, and even pay the imposed fines and litigation fees. For some managers it becomes a financial business decision rather than a decision based on ethics.

Some students will argue for tougher jail sentences. Until recently, white collar crime rarely resulted in incarceration. Warren Buffett, along with other business experts argue that jail time may indeed be a deterrent for many executives as long as they perceive that the legislation will be enforced. Sarbanes Oxley (SOX) is an example of legislation that is structured somewhat differently than environmental legislation, for example. While environmental legislation primarily uses fines as its means of enforcement, SOX specifies jail terms for executive officers that sign off on fraudulent financial statements. SOX also provides job protection for "whistleblowers" that witness fraudulent behavior and step forward to reveal these activities. Initially the expectation was that SOX should provide a legislative incentive for executives to provide accurate financial information and have appropriate documentation and accountability in place. However, SOX has received criticism thus far in that few violations have resulted in jail time.

\section{To what extent is a company obligated to forgo profits in order to conduct itself in an ethical manner? How is this accomplished in a capitalistic society? How can individuals help?}

There are many companies that have done both big and small measures to encourage a more ethical culture. Some companies have implemented ethical practices education to encourage employees to think about the ethical implications regarding their decisions. Others have gone much further by becoming leaders in the area of business ethics and corporate responsibility. The documentary shows us how Ray Anderson, CEO of Interface became a leader in the area of corporate responsibility by making dramatic changes to eliminate waste and harmful emissions. He worked hard to gain stakeholder support in the need for sustainability and has remained a viable and profitable organization since this effort. Other well-know companies have followed suit. For example, BP, Stonyfield Farm, 
Avon, Inc., the Body Shop, Timberlake and Hewlett-Packard have all made dramatic changes to improve outcomes for all stakeholders and still remain profitable. ${ }^{3}$

The documentary talks about how individuals can certainly have an impact through protests, boycotts, litigation, and consumer dollars. The citizens of Arcata, CA voted to exercise democratic control over companies. They were able to ban future corporations from developing in Arcata and limited fast food chains to nine. Activists were able to overturn legislation prohibiting the gathering of seeds in some countries in order to force them to buy more.

However, it doesn't always take a large movement. Small steps help in this quest as well. Individuals can take small steps to implement change by being aware of who the company's stakeholders are and encouraging ethical practices and cultures in the firms so that all stakeholders benefit.

\section{SUMMARY}

This paper presented some discussion questions that can be used to initiate a thoughtful classroom discussion of the many business decisions managers must make that could have some questionable consequences on others. The documentary, "The Corporation" is an excellent way to provide students with some frame of reference for the discussion. The objective of the exercise is to emphasize to students that as future business managers they need to understand and assess the impact their business decisions have on other stakeholders of the corporation. Furthermore, as consumers and investors, they need to think about how they 'vote' with their dollar today.

\section{REFERENCES}

1. Arena, Christine. Cause for Success: Ten Companies That Put Profits Second and Came in First, (2004), New World Library, Novato, CA.

2. Carroll, Archie B. "The Four Faces of Corporate Citizenship," Business and Society Review, 100 (September 1998), pp. 1-7.

3. Chan, K. C., M. Weber, M. Johnson. "Using Other People's Money in the Classroom," Financial Practice and Education, 5:1 (Spring/Summer 1995), 123-127.

4. Dyl, E. A. “Wall Street: A Case in Ethics," Financial Practice and Education, 1:1 (Spring 1991), 49-51.

5. Hatfield, P. A. and A. Buchko. "Using ENRON: The Smartest Guys In the Room As a Live Case Illustration of Financial Concepts and Ethical Issues," Working Paper, (2007) Forthcoming Issue of Journal of Financial Education.

6. Hollender, Jeffrey and Stephen Fenichell. What Matters Most: How a Small Group of Pioneers is Teaching Social Responsibility to Big Business, and Why Big Business is Listening, (2004), Basic Books.

7. Nofsinger, J. R. "Barbarians at the Gate: A Capstone Corporate Finance Project," Financial Practice and Education, 5:1 (Spring/Summer 1995), 118-122.

8. Serey, T. "Carpe Diem: Lessons About Life and Management From Dead Poets Society," Journal of Management Education, 16:3 (August 1992). 374-381.

9. Shaw, William H. and Vincent Barry. Moral Issues in Business, 10th Edition. (2007), Thomson-Wadsworth Publishers, Belmont, CA.

\footnotetext{
${ }^{3}$ For additional details on actions taken by these companies see, Cause for Success: 10 Companies that Put Profits Second and Came in First by Christine Arena, (2004), New World Library, Novato, CA.
} 


\section{NOTES}

